
氏 名 (本 籍)
屋 部登志族
学位の種類医学博士
学位記番号博 甲第 314 号

(東京都)

学位授与年月日 昭和 60 年 3 月 25 日

学位授与の要件 学位規則第 5 条第 1 項該当

審 査 研 究科医学研究科生物系専攻

学位論文題目

The MT 3 Specificity Resides on a Novel Human Class II Antigen Distinct from the HLA-DR Antigen and DC-like Antigen

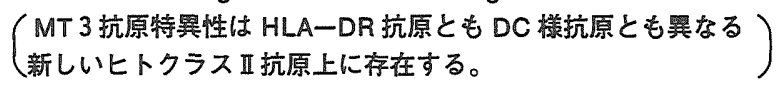

\begin{tabular}{|c|c|c|c|c|c|}
\hline 主 査 & 筑波大学教授 & 医学博士 & 田 & 村 & 昇 \\
\hline 査 & 筑波大学教授 & 医学博士 & 橋 & 本 & 達一郎 \\
\hline 査 & 筑波大学教授 & 医学博士 & $\equiv$ & 澤 & 章 \\
\hline 査 & 筑波大学助教授 & 医学博士 & 柏 & 木 & 平八郎 \\
\hline 副 査 & 筑波大学助教授 & 医学博士 & 藤 & 田 & 禎 \\
\hline
\end{tabular}

論文の 要旨

ヒトの主要組織適合遺伝子複合体（MHC，HLA 複合体）の遺伝子産物のうちのクラス I抗原は, 免疫応答, 移植片対宿主反応, ある種の疾患に対する感受性などに関連する抗原として, 近年とく に重要視されている。このクラス II抗原としては，DR 抗原，DC 抗原，SB 抗原の少なくとも 3 種 類の抗原系が確認されてきたが，さらにこれらとは異なる抗原特異性を示す MT 3 抗原の存在が報 告されている。この MT 3 抗原に関しては, その抗原特異性がDR 抗原系のDR 4, DR 7, DRw 9 抗原と強い相関を示すことから DR 超特異性と呼ばれ DR 抗原分子上に存在するとする報告と, DC 抗原上に存在するという報告，新しいクラス四抗原上に存在するという報告などがある。この混乱 の一因は，異種抗血清である単クローン性抗体の使用にある。本研究は，同種抗原決定基のみを認 識する同種抗体を使用することにより，MT 3 抗原特異性の存在する抗原分子と既知のクラス II 抗 原との異同，およびその遺伝的支配を明らかにしょうとしたものである。

材料と方法：DR7, DRw 9, DR 4 ホモ接合のヒト株化 B リンパ芽球様細胞をそれぞれホモジナ イズした後, 遠心分離法により細胞膜を分離し，さらにレンチルレクチンアフィニィティークロマ トグラフ法により細胞膜糖タンパク質を精製した。これをクロラミン T 法により ${ }^{125} \mathrm{I} て ゙$ 標識して抗 MT 3 , 抗 DR, 抗 DC 様各同種抗血清との間で免疫沈降反応を行った。沈降物を可溶化し二次元電 
気泳動法により分離した。各ポリペプチド鎖スポットの検出はオートラジオグラフ法で行った。ま た各クラスI抗原の相対量を比較する為に細胞膜糖タンパク質を二次元電気泳動法にて分離後, クーマシーブルーで染色した。

結果と考察：DR 7 細胞の MT 3, DR, DC 各抗原を比較する為に細胞膜糖タンパク質から免疫沈 降された DR 7, MT 3, MB 2 (DC抗原) 各抗原を二次元電気泳動法で解析した。抗 DR 7 血清は 1 組の $\mathrm{H}$ 鎖と L 鎖のみを特異的に沈降させた。これらは DR 7 抗原の構成ポリペプチドであると考 えられる。抗 MT 3 血清は DR 7 抗原 $L$ 鎖と共に 1 組の H 鎖と L 鎖を沈降させた。この L 鎖は抗 MT 3 血清特異的に沈降されるのでMT 3 抗原 L 鎖と考えられる。一方 H 鎖は DR $7 \mathrm{H}$ 鎖と同一の 電気泳動上の易動度を示した。DR 7 抗原が共沈したのは抗 MT 3 血清中に抗 DR 抗体が少量混入し ている為と考えられる。抗 MB 2 血清は 1 組の H 鎖と L 鎖を沈降した。これらは抗 MB 2 血清特異 的に沈降されるので MB 2 抗原 $\mathrm{H}$ 鎖，L鎖であると考えられる。MB 2 抗原の $\mathrm{H}$ 鎖， L 鎖の電気泳 動上の易動度は MT 3 抗原及び DR 7 抗原それぞれの H 鎖，L 鎖の易動度と異なっている。

各クラスI抗原の相対量を比較する為に細胞膜糖タンパク質を二次元電気泳動法で解析した。ク ラスI及びクラスII抗原は分子量10万以下の細胞膜糖タンパク質の主要な成分を構成していた。ク ラス II 抗原の大部分は DR 7 抗原であり MT 3 MB 2 各抗原の発現量は DR 7 抗原に較べて少量で あることが示唆された。

さらにDRw 9，DR 4 各細胞からそれぞれ免疫沈降された DR, MT 3, TB21各抗原を二次元電 気泳動法で解析した。TB21抗原はその特異性, 細胞分布等よりこれらの細胞の DC 抗原であると 考えられる。各抗原はそれぞれ 1 組の H 鎖，L鎖より構成されていた。L 鎖の易動度は各抗原間で 互いに異なっていた。H 鎖の易動度は，MT 3 抗原と DR 抗原の間では同一であったが，TB21抗原 の $\mathrm{H}$ 鎖はこの両者と異なる易動度を示した。

これらの結果は, MT 3 抗原分子が DR 抗原分子や DC 抗原分子とは異なる分子として存在する ことを明確に示すものであり，その抗原特異性は，その H 鎖が DR 抗原の H 鎖と区別できないこ とから，L鎖上に存在するものと考えられる。そして，この L 鎖をコードする遺伝子座は, DR 抗 原特異性とMT 3 抗原特異性との間で組み換えが観察されていないことから, DR 抗原遺伝子座の ごく近くに位置しているものと推定できる。この推定は同時に，MT 3 抗原が DR 抗原遺伝子座か ら約 2 センチモルガン離れた SB 抗原遺伝子座によってコードされているという可能性をも否定す るものである。

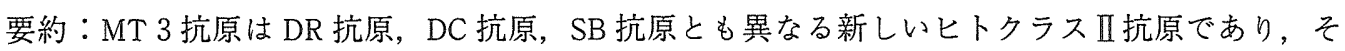
の特異性は L 鎖に存在すると考えられる。そしてこの L 鎖は，既知の遺伝子座とは異なる新しい ヒトクラス抗原遺伝子座によってコードされていると推定される。 


\section{審 查の要旨}

いわゆる D/DR 抗原系と呼ばれるところのヒト MHCクラス II 抗原は，その重要性ゆえに多くの 研究がなされ，同時に混乱を招いている。その原因は，抗原の同定に使用される抗血清が必ずしも 同種抗原のみを認識しているとは限らないところにある。著者は, 同種抗原のみを認識するところ の同種抗体をもつ経産婦血清の中から特異性の高い抗血清を注意墚く選択し，一次元の分離は等電 点の違いにより二次元の分離は分子量の違いによって抗原分子を分けるところの二次元電気泳動法 により，クラスII 抗原を分離同定し，MT 3 抗原が DR 抗原， DC 抗原， SB 抗原とも異なる抗原分 子であることを明確に示している。著者のもちいたこれらの方法は, 同種抗原の免疫学的分析法と しては理想的なものであり，こうした方法でしか正確な情報は得難いと云う意昧においても，これ らの結果は高く評価できる。

よって，著者は医学博士の学位を受けるに十分な資格を有するものとみとめる。 